\title{
Fiscal austerity, the Great Recession and the rise of new dictatorships
}

\author{
Hassan Bougrine* \\ Full Professor of Economics and Finance, Laurentian University, Ontario, Canada
}

\begin{abstract}
Austerity measures have been tested in developing countries for several decades under the pseudo name of 'structural adjustment programmes' following the recommendations and under the supervision of the World Bank (WB) and the International Monetary Fund $(I M F)$. Evidence indicates that the economic and social consequences of these policies have been so disastrous that there is now more poverty and more inequality than a generation ago. The same scenario is being proposed as the alternative to what has hitherto been labeled a social-democratic economic system in industrialized nations. The economically dominant minority has largely succeeded in imposing its neoliberal agenda by convincing the general public, through various means, of the need for austerity. The paper challenges the erroneous theories on which austerity is based and proposes an alternative explanation to what is the 'best practice' in public finance. It argues that deficit spending by the government is an important policy tool that can be successfully used to guarantee full employment and create wealth and prosperity for the whole society.
\end{abstract}

Keywords: austerity, fiscal policy, deficit, debt, creative state

JEL codes: $E 58, E 62, H 62, I 38$

\section{INTRODUCTION}

Scholars who studied the evolution of modern societies generally agree that government policies are very powerful tools that shape the economic and social environment within which human activity is carried out. This is particularly true in a capitalist economy where decisions in the private sector are highly sensitive to the type of economic policies adopted by the government. The role played by governments in the expansion of colonialism and in the development of industrial capitalism has been widely acknowledged by various scholars but it was John Maynard Keynes (1936) who brilliantly formulated one of the basic premises of the framework for what became called the 'mixed economy' that is, one in which the government plays a major role in stimulating aggregate demand and in helping regenerate the dynamism of the economy as a whole.

In fact, this was Keynes's major contribution to macroeconomics. These ideas helped to save the capitalist system from collapse and later promoted its stability for one whole generation. The rise of the welfare state meant that citizens benefited from various social programmes such as unemployment benefits, social security, and so on. Stabilization policies became widely used after the Second World War and governments relied on

* I thank a referee of this journal for useful suggestions and constructive comments. Any remaining errors or shortcomings are mine. 
them to lessen the length of the downturn as well as the severity of its impact (costs in terms of profit loss, unemployment). Governments achieved this objective by accepting the necessity to go into deficit in order to finance spending on public investment such as in education, health care and public infrastructure. Up until the 1970s, deficit spending was regarded as the 'normal' practice of a successful expansionary fiscal policy.

Keynes's critics called his 'interventionist' strategy an assault on economic freedom and a threat to the foundations of capitalism - alleging that it gradually seeks to install dictatorship through government's regulation, control and arbitrary power. The objection to government intervention is often justified on grounds related to the assumed 'public sector inefficiencies' that result from the 'misallocation of resources' and the unfairness in using 'public funds' to support private interests such as uncompetitive businesses and voluntarily unemployed workers. Consequently, these critics call for a 'more efficient public sector' and a 'fiscally responsible' government - and obviously for deregulation of all markets and privatization of the public sector activities, including social security. These, and similar, policy recommendations largely formed the backbone of what is often referred to as the neoliberal agenda, which has dominated economic policy at least since the 1980s. In practice, this meant severe austerity measures that resulted in massive cuts in government spending with the stated objective of eliminating budget deficits and reducing or eliminating the public debt, which came to be viewed as a burden on present and future generations.

However, a careful analysis leads us to conclude that the ultimate objective behind these policies was the subjugation of labor and its subsumption to finance. And for this purpose, fiscal austerity proved to be a useful means because it forces the middle and low income groups to shoulder additional costs in order to have access, for instance, to education and health care services, as these become privatized. In the context of rising unemployment and stagnant or falling real wages, the rational reaction of the low and middle income groups (referred to here as the masses) is to resort to borrowing - thus fulfilling the expectations of those who are behind the design of these policies, namely the financiers.

Although debt provided a temporary relief for most households, this did not solve their fundamental problem. It has actually contributed to pushing them further into poverty because when they could no longer afford to meet the payments on a rising debt, they simply lost their collateral, which was typically a house. What were the consequences for households when there was no house to hold? They simply break up, and the individual members end up doing part-time, low-paying jobs - again fulfilling the expectations of the engineers of the neoliberal agenda regarding the flexibilization of labor markets and the subjugation of labor.

Austerity measures have actually been tested in developing countries for several decades now, particularly since the 1980s, under the pseudo name of 'structural adjustment programmes', following the recommendations and under the supervision of the World Bank and the IMF. These programmes focused on the so-called 'macroeconomic fundamentals', which directly targeted low inflation through higher interest rates and balanced budgets through cuts to public spending on social services (including the elimination of subsidies to basic foodstuffs), the sale of public corporations, liberalization of trade and capital accounts and deregulation of all markets; thus allowing unrestricted access to transnational corporations to natural resources and other vital sectors. ${ }^{1}$ The experience of several developing countries in Africa and Asia shows that

1. This process is commonly referred to as globalization but Palley (2007) has, correctly, called it financialization because it specifically seeks to advance the agenda of the dominant financial interests. 
economic policies based on these recommendations have clearly hindered economic growth and pushed millions of people into poverty, illiteracy, etc. while enriching a small but very powerful minority - thus widening the inequality gap (Stiglitz 2002; Loxley 1998; Campbell and Loxley 1989).

Although it might seem overly fearful, it is my contention that this same scenario is being envisioned for the industrialized economies. We are slowly and quietly sliding down the path of what I call here a new type of dictatorship - that is, a regime in which a minority succeeds in imposing, smoothly and via legal means, its views and values; and above all the economic model that best serves its interests. In such a regime, the masses are denied their economic and social rights (to employment, unemployment benefits, etc.) as the state, on behalf of the minority, dismantles social programmes by withdrawing its financial support. Indeed, unless there is a policy reversal, Crotty (2012) fears that what he calls the 'great austerity war' might just be won by a coalition of 'right-wing' neoconservatives and libertarians. Unfortunately, the likelihood of a policy reversal in the near future is made quite small by the fact that austerity is nowadays accepted even by those on the 'left', such as the socialists and the social democrats in Europe who make deficit and debt reductions their top priority. A review of the political discourse by finance ministers in Canada (see Lavoie 1993) and in several EU countries, reveals that the same arguments (favoring austerity) have been made regardless of which party is in power.

Fiscal austerity is now sanctioned by law in several countries. The idea, of course, is to make the government's commitment to fiscal austerity legally binding, but the economic reasoning behind it is to strip the state of its power and sovereignty, particularly in the area of money and finance - thus opening the field for private international money lenders who use their own rules to assess the creditworthiness of borrowers, be they governments or businesses. As a consequence, many national governments have now lost their power to conduct fiscal stabilization policies, even in periods of recession. The latest events in Europe are the best example. Greece, for instance, lives through this tragedy because it has surrendered its monetary sovereignty and accepted the Maastricht and Amsterdam treaties, which limit budget deficits to 3 percent of GDP and the public debt to 60 percent of GDP. Following the European Monetary Union example, and under pressure from international financial institutions, central banks in several developing countries have also sought and gained independence by changing the decrees or legal acts governing them to clearly state that they are prohibited from 'advancing cash to finance government spending'.

This paper challenges the dominant views on fiscal austerity and offers alternative ideas on the relationship between budget deficits and economic performance. Using data from Canada as an example, it shows that deficits in the public sector are actually a source of income and wealth for the private sector. Based on this evidence, the paper concludes that austerity measures must be rejected and replaced by policies that are consistent with the 'functional finance' approach. In the section 2 , I argue that prolonged austerity measures have led to the concentration of wealth in the hands of a minority of financiers and contributed to creating an environment that was conducive

2. For instance, the statute of the central bank of Morocco (dated 2005) states, in its Article 27, that 'The Bank cannot give financial support to the State nor can it guarantee commitments made by the State, except in the form of overdraft facilities ... The overdraft facility is limited to five per cent of the fiscal revenues collected during the previous fiscal year. The time period for using this facility cannot exceed 120 days, consecutive or not, during a given fiscal year' (my translation). The statute is available online from: http://www.bkam.ma. 
to the current crisis. Section 3 critically examines the ideology behind the neoliberal economic model and proposes an alternative explanation to deficits, public finance and money. Conclusions are given in the section 4.

\section{FISCAL AUSTERITY AND THE GREAT RECESSION: PAUPERIZING THE MASSES}

The type of economic model that has been implemented since the end of the 1970s and the beginning of the 1980s has two main features: (1) on the fiscal front, the dominant practice has been to put an emphasis on fiscal austerity in order to justify cuts to government spending, particularly on public infrastructure and social services - but with a notable exception to military spending and bails-outs of too-big-to-fail financial institutions, ${ }^{3}$ (2) central banks declared inflation as the main economic problem and set out to fight it via, among other things, higher interest rates and more unemployment.

What this means is that both arms of government, namely the Treasury (ministry of finance) and the Central Bank, are used to steer the economy in a direction that benefits primarily the influential financial interests. In this context, it is important to emphasize that the repeated recessions that hit most industrialized economies since the 1980s have been at least partly engineered by neoliberal policies. It is equally important to note that the ensuing and prolonged period of stagnation has greatly benefited a minority of the population whose wealth expanded at unprecedented rates. In the US, for example, data indicate that financial institutions' assets, which are essentially securities, grew by nearly 8000 percent between 1980 and 2007, reaching almost US $\$ 12$ trillion - that is, about 84 percent of GDP of the same year (see Figure 1).

The ideology behind these 'predatory' policies has been criticized extensively elsewhere (Galbraith 2008; Wray 1999) and suffice it here to briefly summarize the impact of such policies and show how they have contributed to the creation of a weak economic environment that was conducive to the crisis. As we can see below, evidence indicates that the immediate consequences of these policies have been harmful to the economy. The long-term consequences have been even more serious because they have affected the distribution of income and wealth - tilting it in favour of the rich. In particular, the deregulation of markets and the sale of public corporations (privatization) that accompanied fiscal austerity weakened labor and increased unemployment but greatly benefited those who had already accumulated an enormous financial wealth - thus reinforcing the trend toward higher inequality. For instance, Yalnizyan (2010) reports that the richest 1 percent of Canadians received 31.8 percent of growth in total income between 1997 and 2007 as opposed to only 8 percent during the earlier period from the late 1950s to the late 1960s. Taxes were also used in a way that benefited the rich and penalized the poor. Indeed, Figures 2 and 3 show that inequality, as measured by the Gini coefficient (after taxes), has increased even in the Nordic countries where income distribution was becoming more egalitarian after the Second World War.

The deregulation of labor markets succeeded in rendering work more precarious and flexible, which meant that capitalists-entrepreneurs could hire and fire workers with ease by maintaining only some type of a sub-contractual relationship with them. This was accompanied by a decline in unemployment benefits, unionization,

3. The popular reaction to such a flagrantly biased policy has been: 'we get the austerity, they get the stimulus'! 


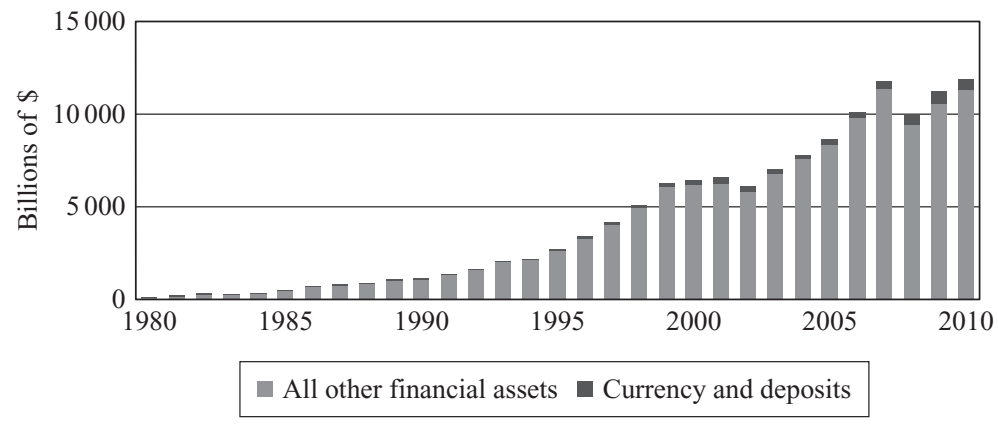

Source: OECD database.

Figure 1 Financial assets of institutional investors in the US

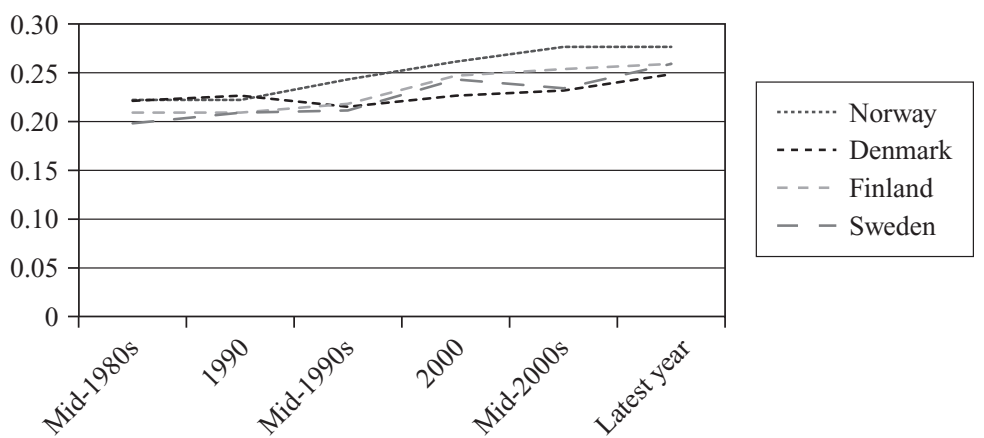

Source: OECD database.

Figure 2 Gini coefficient (after taxes and transfers) for the total population in Scandinavia

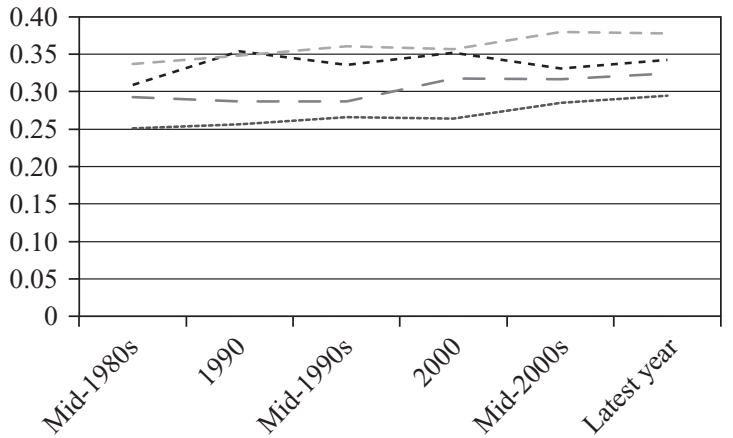

$$
\begin{aligned}
& \text {........ Germany } \\
& \text {-...- UK } \\
& --- \text { USA } \\
& \text { - - Canada }
\end{aligned}
$$

Source: OECD database.

Figure 3 Gini coefficient (after taxes and transfers) for the total population in Germany, the UK, US and Canada 
114 Review of Keynesian Economics, Inaugural Issue

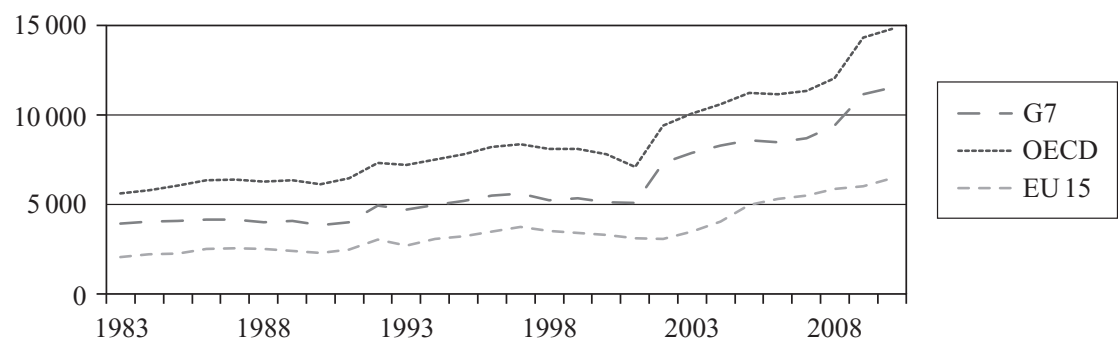

Source: OECD database.

Figure 4 Involuntary part-time workers (in thousands)

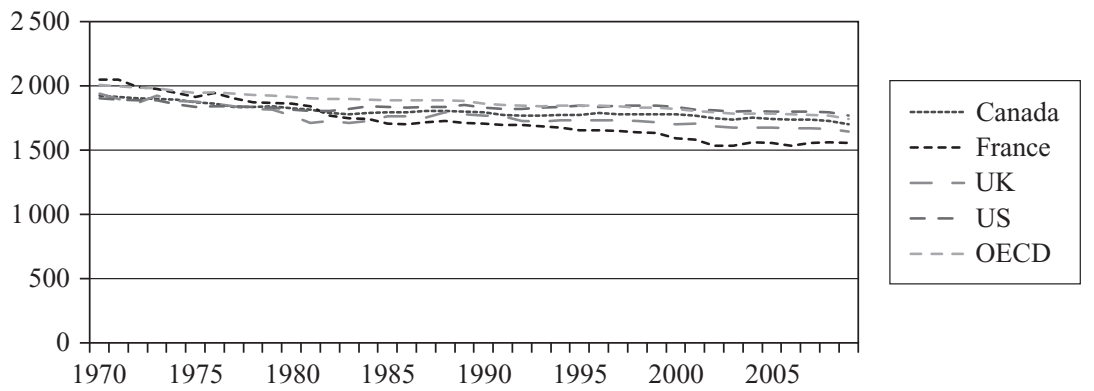

Source: OECD database.

Figure 5 Average annual hours actually worked per worker

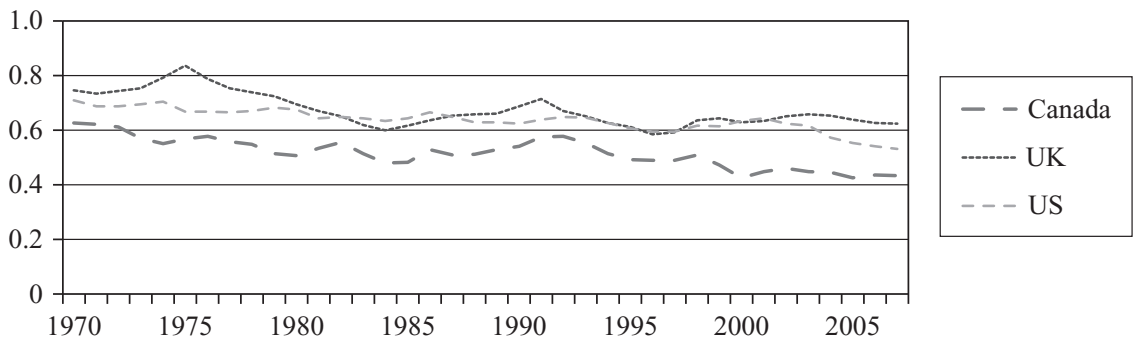

Source: OECD database.

Figure 6 Labor income shares in Canada, the UK and US

and workers' rights in general. Figure 4 shows that the number of involuntary parttime workers increased steadily in virtually every industrialized country since the 1980s while Figure 5 shows that the number of hours actually worked per worker had been declining since the 1970s. The result was, as expected, a shrinking share of labor income in the gross domestic product (see Figure 6) and an increase in inequality. All these changes are part of a larger agenda that seeks to achieve what Bellofiore (2011) calls the 'real subsumption of labour to finance', which is a major characteristic of finance-dominated capitalism. 
In an effort to reinforce this trend, the Canadian government, for example, has recently tabled its budget bill for the year 2012, which contains a reform of the EI (employment insurance) program that makes it harder for workers to qualify for benefits when they become unemployed. The reform removes existing definitions of work that EI recipients can turn down as 'not suitable', either because it is not in their usual occupation, pays less or is performed in conditions less favorable than the conditions that claimants usually obtained. At the same time, and in order to exert further downward pressure on wages, the government allows employers to pay highly-skilled 'imported' temporary foreign workers up to 15 percent less than the prevailing local wage. ${ }^{4}$ In defense of his 'pay-less wage model', the Canadian finance minister argued that 'people will have to engage more in the workforce ... There is no bad job - the only bad job is not having a job' (Toronto Star 2012). The same scenario is being implemented in the EU zone where governments in several countries have resorted to large layoffs from the public sector to create an atmosphere of fear and insecurity among the reserve army of the unemployed.

This state of labor markets has created an 'overworked' laborer (to borrow Schor's expression; Schor 1993) who increasingly needed to work more hours or to take additional part-time jobs but was still unable to make ends meet. The saving rates declined dramatically and consumers/households were forced, in the end, to resort to borrowing in order to preserve some of their living standards. Banks welcomed this change and encouraged it because they found in it a new source of profits, particularly with the spread of securitization and derivatives such as MBSs (mortgage backed securities). Middle-class and even poor households were encouraged to take loans to buy homes, new cars and appliances, or even ordinary consumption items. ${ }^{5}$

Rising household debt became the backbone that supported growth for most of the 3 decades that followed the 1980s in several countries, including the US (Palley 2009). However, the service of a rising debt represented an increasing proportion of disposable incomes and worsened households' financial situation. This contributed further to the concentration of wealth and created a more unequal society in which 'the top $1 \%$ of the population control $40 \%$ of the total wealth', such as in the case of the US (Stiglitz 2011). Therefore, the long-run consequences of austerity policies resulted in a higher concentration of wealth in the hands of a minority on one hand and a mass of 'industrial reserve army' of workers on the other - with their ability to work as their only fundamental asset.

It is here that we find the source of the current crisis: lending to low income groups, or even to those who have no income, no job and no assets (NINJA), aka a subprime category, is the business of wealthy individuals and financial institutions. It binds borrowers to banks in the so-called money market where loans, which are banks' assets, now become commodities that are bought and sold on the securities market - thus

4. In the early years of neoliberal globalization (the 1970s and 1980s), when capital mobility was fervently defended, transnational corporations negotiated lower wages and benefits by threatening to move their production facilities to the underdeveloped world where cheap and docile labor pools existed, but in the newer version of globalization, labor is also rendered more mobile in the sense that it is imported whenever needed, just like any other commodity, used for the time needed and discarded and sent back when the job is done. This practice is common in Europe and North America and is found in all sectors from strawberry pickers in Spain to nurses in Canada and the US (Valiani 2012).

5. According to the OECD database, long-term households' loans in the US are essentially for house purchases whereas short-term loans are for financing consumption purchases and represent on average 25 percent of total loans for the period 1995-2011 (see OECD database). 
marking the shift to the 'originate and distribute' model. It is important to emphasize that the source of the supply of these securities resides primarily with the banking sector which packages the various relational contracts (mortgages, corporate debt, etc.) into securities and offers them for sale to the so-called 'investors' on financial markets. These packages or portfolios are then organized into different tranches with varying degrees of risk ranging from the safest (super senior tranche) to the most junior tranche or toxic waste.

The phenomenal growth of financial assets documented in Figure 1 indicates that the demand for these securities has been extremely high. Such high demand can only be justified in two cases: (1) if the return is relatively high compared to the risk involved; and (2) if the investors have accumulated large amounts of liquidity which needed to be recycled. With the benefit of hindsight, it is now clear that both of these factors prevailed during most of the last 2 decades of the twentieth century (Credit Suisse 2011), which explains the euphoria that preceded the Great Recession.

In the first case, this was a period of speculative bubbles (see Palley 2009) and the return was almost always 'a sure thing', thanks also to the rise of credit default swaps (CDS), which allowed the buyers of these securities to insure themselves against the risk of default. In fact, even without buying anything, speculators could simply place a bet against the possibility of default of certain securities (such as bonds issued by the government of Greece) and purchase credit default swaps. Speculators would pay, for example, a monthly fee to the insurer in exchange for a payment in the case their bet materializes. On the other hand, the need for recycling the accumulated wealth, and the quest for a higher yield, is imperative for its growth and expansion; otherwise it must necessarily be withdrawn from circulation. ${ }^{6}$

There is therefore a disproportionate pressure coming from the demand side of the market for financial securities, particularly when we consider the historic low returns on government bonds. ${ }^{7}$ But having now discovered that a higher supply of these securities hinges on the expansion of relational contracts, the suppliers, namely the banks, rationally responded by pushing for the increase of the number of these contracts, which was done by including additional borrowers, even of the NINJA type; hence the emergence of the subprime loans or the subsumption of labor to finance.

In conclusion, if the subsumption of labor to capital can be described as a situation in which the capitalist-entrepreneur succeeds in asserting his/her domination by establishing a set of contracts with independent workers who are now 'bound only by the need to make contracted deliveries at the stipulated time' (Rajan 2012, p. 6), the subsumption of labor to finance would be quite simply a situation in which money

6. As Marx (1887 [1967]) put it, 'The restless never-ending process of profit-making alone is what [the capitalist] aims at. This boundless greed after riches, this passionate chase after exchange-value, is common to the capitalist and the miser; but while the miser is merely a capitalist gone mad, the capitalist is a rational miser. The never-ending augmentation of exchangevalue, which the miser strives after, by seeking to save his money from circulation, is attained by the more acute capitalist, by constantly throwing it afresh into circulation.' Available online http://www.marxists.org/archive/marx/works/1867-c1/ch04.htm.

7. The Credit Suisse Global Investment Returns Yearbook (Credit Suisse 2011, p. 5) reports that in "the USA, over the period from the start of 1980 to the end of 2010, the annualized real (inflation adjusted) return on government bonds was $6.0 \%$, broadly matching the $6.3 \%$ longterm performance of equities. Over the preceding 80 years, US government bonds had provided an annualized real return of only $0.2 \%$. Similarly, for the UK, from 1980 to 2010 the annualized real return on government bonds was $6.3 \%$. Over the preceding 80 years, UK government bonds had provided an annualized real return of just $-0.5 \%$.' 
managers succeed in developing clever ways to get a hold of those contracts and transforming them into new financial products - thus insuring at the same time that workers' income receipts are diverted back to financial institutions in the form of debt payments, potentially serving as income streams for the holders of these assets. On this account, financialization is the exploitation of the poor and austerity is the disciplining rod that ensures their submission.

\section{IDEOLOGY AS THEORY: THE RISE OF NEW DICTATORSHIPS}

Austerity clearly aims at dismantling the social programmes which were built after the Second World War by the 'welfare state' in an effort to avoid a return of the disastrous effects of the Great Depression. For this reason, one would expect that any policy measure based on austerity should be rejected by the majority of the population. Unfortunately, with the exception of a few dissident voices in academia and some isolated popular revolts (for example, Greece, Spain, Argentina), austerity is widely applauded by policymakers around the world, ${ }^{8}$ by professional economists and, ironically, by those who are hurt most by it - that is, the masses. ${ }^{9}$

It is perhaps understandable that attempts to impose the economic model based on austerity are relatively easily implemented in some developing countries because these are governed by despotic dictators who have all the time and the means needed to implement such an agenda. But why on earth would the masses, in a democracy, freely elect and re-elect, for over 3 decades now, political parties that impose austerity on them and whose platform and political narrative clearly state that they seek to eliminate the public debt and balance the budgets (or achieve surpluses), mainly through cuts to public spending and higher taxes?

The short answer is that, yes, people are gullible, willing to trust their political representatives but above all they are ignorant about the meaning of budget deficits, public debt and public finance in general. The general population cannot be blamed for lacking such an expert knowledge when even the learned and well-intentioned economists support austerity measures. Other economists (including Nobel Prize laureates such as Paul Krugman) would accept some deficit spending during recessions but they definitely want a return to 'fiscal responsibility' when the economy is growing so that the budget is balanced over the business cycle. It seems that the cultural conditioning through indoctrination by neoclassical economics which dominated economic thought and policymaking during much of the last century has paid off since its views of 'sound finance' are now well ingrained in the minds of most people - thus making it easier for a minority of financiers to hijack public policymaking.

This lamentable situation has visibly frustrated many scholars who think differently and see in budget deficits and fiscal policy an instrument that can be successfully used to guarantee full employment and create wealth and prosperity for the larger

8. However, policymakers in most industrialized countries tend to be pragmatic about deficit spending and often become de facto Keynesians particularly during recessions, as the latest events have shown (see Hodgson 2009; Foley 2010).

9. In fact, it is quite tragic that in the Arab world, the latest revolts which came to be known as the Arab Spring claimed thousands of lives but in the end the majority of the population settled for regimes whose economic and social programmes are openly based on austerity measures and blessed by the IMF (for example, Tunisia, Egypt). 
population. Paul Davidson (2010, p. 664), for instance, who is a long-time defender of this view, after reviewing the history of fiscal policy in the US since the 1920s, concluded that:

Just as we expect the Federal government to spend whatever is necessary to protect us from foreign enemies during a war, we should also expect the government to spend whatever is necessary to protect us from the economic terrorism of a great recession. The public must be educated to understand that a civilized society is one that assures both domestic workers and enterprises prosper and that the intelligent use of government fiscal policy can assure that total market demand is always sufficient to generate domestic profits large enough to create a fully employed economy.

Adding - perhaps more for emphasis rather than for clarification - that:

If wars are not sufficient (or necessary) reasons to raise taxes or cut government spending sufficiently to balance the budget while protecting the nation, then why should defending the nation against serious economic threats require a balanced budget or a lower deficit? Our politicians and the public must be educated to understand that when total demand for domestically produced goods is low so that recession and depression threaten, then government must deficit spend as much as necessary to encourage domestic entrepreneurs to hire all American workers who are willing and able to work. (Davidson 2010, p. 665)

Similarly, in a recent study, James Crotty (2012) gave an excellent review of the economic and political history of the USA since the 1920s, with a focus on the two divergent views regarding the role of government in the economy. As Crotty (2012) explains, the divergence in views led to a clash between those who advocated social democracy or some type of regulated capitalism - whose views largely contributed to the creation of the New Deal project and, on the other hand, a coalition of right-wing conservatives who consider government control as a threat to liberty, economic freedom and free enterprise. By putting the current debate on austerity in its historical context, Crotty's analysis evidently offers a much better understanding of what is actually involved.

Indeed, Crotty (2012, p. 82) notes that the programmes contained in the New Deal 'included strict regulation of financial markets, creation of the Social Security programme, support for the rising industrial union movement, large public employment programmes, deficit-financed stimulus spending of various kinds and the beginning of a system of unemployment insurance. The New Deal helped stop the collapse of the economy and restored economic growth, but when the Democrats tightened the budget in 1937 under pressure from antideficit forces, unemployment began to rise again. It took the central planning and huge government spending of the Second World War to restore full employment and create general prosperity.'

By contrast, the right-wing conservatives, then and now, seek to defeat the New Deal project and to force a return to the low-tax economic model that prevailed during the 1920s and in which 'From 1923 to $1929,70 \%$ of the growth in income went to the richest $1 \%$ and only $15 \%$ went to the bottom $90 \%$ of the income distribution.' To achieve their objective, Crotty (2012, p. 84) notes that austerity advocates have now formed

a political alliance between resurgent right-wing economic forces and the rapidly increasing ranks of cultural conservatives. As a result, business and other conservative forces saw a dramatic increase in their ability to raise money to elect friendly politicians, organise grass-roots pressure on all politicians, and spend money on an expanding right-wing ideological 
infrastructure of think tanks and university influence. They also used their control of the media to interpret economic and political events for the public through a conservative prism. As top executives from giant corporations began to shift toward more aggressive conservative economic positions, they created a formidable fund-raising and lobbying operation. Wealthy right-wing families also poured money into the political process.

This leads us to explore a more complex answer to the above question as to why electors in a democracy would give their votes to policymakers who repeatedly seek to impose austerity on them and make their lives miserable. To be sure, it is out of the question to even imagine that people might willingly choose to inflict such punishment on themselves. Indeed, if you ask ordinary people whether they would rather pay for health care and education or have these services provided by the public sector, they would choose the latter option without hesitation. Similarly, the majority of people would choose to have in place a social security system and an unemployment benefits programme in case they fail to do well in the market system. ${ }^{10}$ In fact, these are rights for which workers have fought since the rise of industrial capitalism. People would also support government initiatives (for example, public infrastructure, subsidies, etc.) to stimulate the economy in case of a recession if the goal is to create jobs. This means that the majority of the population is instinctively and rationally against austerity. Yet, at the same time, you tell them that budget deficits are too large, that the public debt is becoming a heavy burden on society and they will put you in charge to fix that (take the latest referendum in Ireland on EU fiscal austerity pact as an exemplar). ${ }^{11}$ This is the area in which 'politicians and the public need to be educated'.

A first step in this learning process is to understand that our society is characterized by conflicting economic interests and that these conflicts are rarely if ever settled in amicable discussions over a cup of coffee. In defending their interests, individuals and the social classes to which they belong are willing to use various means, including violence. In particular, the economically dominant social class uses its privileged position to mobilize the state apparatus (with all its institutional arrangements: education, the police, legislation, etc.) as well as its access to money to finance operations that would help to impose its ideology on the other classes and to bring them into submission for the purpose of further advancing its own interests.

This is not specific to modern capitalist societies. Class struggle, according to Karl Marx, is a central fact in the evolution of societies. In his review of Marx's and Engels's theory of the state, Henry (2008, pp. 16-17) summarized the nature of this struggle by stating that: 'Given different social relations in production, different economic interests prevail and different economic interests demand different political interests. If the interests of some are to prevail, the interests of others must be suppressed. This requires coercion, and coercion requires a state. ... Essentially, the economically dominant class utilizes its dominance to erect a power that acts in the

10. Several polls indicate that the majority of Canadians are in favor of, and willing to pay, higher taxes if the goal is to protect social programmes such as health care, education and pensions. See for instance: http://www.cbc.ca/news/politics/story/2012/04/10/pol-broadbent-poll. html.

11. The EU fiscal compact or European Union's deficit-fighting treaty as commonly referred to has been voted by a majority in Ireland on 31 May 2012 because the proponents told voters that 'this treaty strengthens the economic and budgetary rules ... It will create stability in the euro zone that is essential for growth and job creation'. See http://www.guardian.co.uk/commentisfree/2012/ jun/01/ireland-referendum-yes-recovery. 
interests of that class ... and through its various instruments of rule, the dominant class coerces the ruled class into obedience.'

However, if we want to reform capitalism rather than reject it, ${ }^{12}$ we can argue that resolving the social conflicts about sharing the economic pie does not have to result in a zero-sum game nor does the state have to be necessarily an instrument serving only the interests of the economically dominant class. This is the broad principle on which social democracies were built. At this juncture, it must be noted that the relative success of the minority in imposing its neoliberal agenda and the concomitant rise of new dictatorships revolves around the clever use of three instruments: (1) imposing generalized economic insecurity (unemployment, illiteracy, ignorance and fear) to discipline workers and the general public through austerity measures; (2) writing the curriculum to ensure cultural conditioning and the spread of its ideology through the education system; and (3) engaging in the falsification of history for the purpose of misleading and deception through an army of 'intellectuels faussaires'. ${ }^{13}$

According to Frank $(2012$, p. 11), '... there is nothing really novel about the idea that free markets are the very essence of freedom. What is new is the glorification of this idea at the precise moment when free-market theory has proven itself to be a philosophy of ruination and fraud'. Behind this glorification stand the falsifiers of history who are attempting to 'construct an alternative reality' by giving a false reading of events such as the New Deal and the role of stabilization policies after the Second World War. The 'intellectuels faussaires' supply them with a set of erroneous theories about market efficiency, the virtues of free and unfettered markets, the risks of government regulation, money creation and fiscal policy in order to claim that fiscal 'irresponsibility' and 'easy money' are responsible for recessions and financial crises. The convoluted solutions they offer - with fiscal austerity as their unifying thread seek to privatize everything from health care to education, thus forcing those who cannot pay to become ill and ignorant: a loss of dignity that no one accepts. Austerity is a threat to the freedom and dignity of the individual. Such a threat is a main feature of despotic regimes.

It is in this context that we can speak of a 'creative state' (Whalen 2008) - that is, one that chooses to ally itself with the majority of the population and strive to eradicate poverty by mitigating the effects of risk, uncertainty, and ignorance. If the neoliberal state aims at using austerity to create fear and economic insecurity, in the "creative state', public expenditure must be geared toward the creation of wealth and prosperity. This can be done by providing job security and offering a job for anyone who is willing and able to work, decent housing, good education and health care, unemployment benefits and social security. These are the basic requirements of a policy that seeks to guarantee a share in economic growth and prosperity for the larger population in a 'wisely managed' capitalism (Whalen 2008). Such a policy is consistent with Minsky's (1986) idea of 'Big government capitalism' in which the government

12. In a recent article, Skidelsky (2010, pp. 334-335) wrote that 'The question is whether we can afford to go along with a system which crashes every few years, with increasingly serious social consequences. It is probably impossible, as well as undesirable, to restore the trade unions as a "countervailing power" in the Anglo-American type of economies dominated by the service sector and high tech manufacture. The liberal solution of breaking up concentrations of big business ("trust busting" as the Americans used to call it) is probably unavailable in the increasingly integrated global market. The key to any restoration of a Keynesian political economy is thus the rehabilitation of the state as an instrument of the public interest.'

13. The expression is used by Boniface (2011) to describe those intellectuals who engage in the spread of 'false truths'. 
must act as an employer of last resort (ELR) as well as support private businesses to help sustain profits. From a democratic standpoint, the formulation of such a policy requires a majority participation in economic management through public consultation and approval by democratically elected parliament $;{ }^{14}$ but to ensure that the stated objective is achieved, economic policies must always be judged by their results, as Lerner (1943) recommended.

The use of public finance is, therefore, at the heart of the controversy about austerity. Whereas the advocates of austerity seek to give a practical meaning to the notion of scarcity of money and try to make it a reality, opponents must prove that such a scarcity is only imaginary and that the budget constraints imposed on government spending are in fact arbitrary. To counter the austerity agenda, the creative state must adopt Lerner's (1943) idea of 'functional finance' as its guiding principle. This requires that the central bank plays its primary role of government's banker - that is, being a lender of first resort and financing all public expenditures. This function of the central bank is, in fact, the main pillar of heterodox analyses concerning the creation of money. Understanding how government expenditures are financed is important if we want to demolish the myths about the presumed need for austerity. What, then, does the alternative theory tell us about public finance and the creation of money?

Mainstream economists argue that government spending should only be financed through taxation. Toye (2000, p. 36), for instance, attributes the existence of the welfare state and its social programmes in developed countries to their success in "establishing the institutions necessary for the direct taxation of the majority of adult population during the first half of the twentieth century.' Referring to the situation in developing countries, he notes that 'The absence of direct personal taxation on the revenue side of the budget is matched by the absence, on the expenditure side, of much spending on social security, education and health services.' The conclusion, according to this view, which is highly misleading (see, for instance, Bougrine and Seccareccia 2002) is that since there are limits to the use of increased taxation 'to raise additional government revenue' and since borrowing and money creation have their own problems (crowding out and inflation), the engineers of the neoliberal model tell us that there is no other choice, no alternative to austerity because money is scarce and the government budget constraint is binding. And so, the future for the low and middle-income classes in terms of wealth and prosperity is bleak indeed.

However, in the field of economic policy there should be no room for such deterministic views. Poverty is not the fate and should not be the destiny of the weak and powerless people in a modern society. Well-designed strategies and good economic policies can produce 'miracles'. I argue here that a sovereign (national) government, with its own central bank, faces no budget constraints and that it can pay for any expenditure - whether it is related to building a new hospital, a school, or a highway, or to the hiring of teachers, nurses, engineers, or street sweepers - simply by creating new money (Bougrine 2010; Wray 2010). Whenever there is need for improving the public infrastructure or for a new 'stimulus package', the government simply orders its

14. To return to the Canadian example, the reform of EI contained in the budget bill is not clearly defined but instead laid out in general terms and simply stating that it removes the existing definitions of 'unsuitable' jobs. The exact definitions will be given several months later, which means that the final version of the reform can be approved then by cabinet alone, without parliamentary approval, once the budget bill is voted and becomes law - therefore institutionalizing the idea of governing by decree. 
central bank to debit its account and to transfer the funds to those concerned, by crediting their accounts at commercial banks with an equal amount.

It is important to note that when the private agents' bank accounts are credited, the balance sheets of commercial banks are increased by an equal amount on the liabilities side (due to the increase in deposits) and on the assets side (since banks now have a claim on the government). Banks' claims on the government in this form are called 'reserves'. Banks can claim these reserves through the central bank, which keeps accounts for both the government and commercial banks. In a setting where the central bank is the banking arm of the government, the central bank executes the operation simply by crediting commercial banks' accounts (that is, by adding to their reserves) and debiting the government's account by an equal amount. In this way, the government becomes indebted to its own bank but government spending has resulted in a net injection of money (liquidity) into the private sector. The government is now running a deficit, but the private sector has a surplus. We conclude that government spending increases the private sector's incomes and, therefore, that the accumulated deficits (the 'public debt') add to the private sector's wealth (see Parguez 2002).

It should be emphasized that levying taxes would lead to the exact opposite of the above operation. That is because, when we pay taxes, our accounts (at commercial banks) are debited and the government's account at the central bank is credited. In the process, obviously balance sheets of commercial banks will have been reduced on both sides by the same amount, since deposits went down and (consequently) banks lost reserves (meaning that their claims on the government decreased). The central bank shows this by debiting commercial banks' accounts and crediting the government's account. At this stage, one can say that the accumulated credits in the government's account at the central bank will now be tallied against the government's debts, which will be reduced or eliminated; however, this has nothing to do with the financing of public spending, since this has already been paid for. If the government collects more taxes than it spends, its account at the central bank will have a surplus, but the private sector as a whole will be in deficit.

The relevance of this accounting principle derives from the basic national income identity and states that:

\section{Domestic Private Sector Balance + Domestic Government Sector Balance + Foreign Sector Balance $=0$}

To see this, assume that the foreign sector has a balanced budget, then a deficit in the government budget must necessarily translate into a surplus for the private sector and vice versa. This is supported by empirical evidence, as many have shown (see, among others, Godley and Lavoie 2007; Bougrine 2010). Figure 7 below illustrates this principle using Canadian data where we have plotted the net lending or borrowing by the consolidated government sector in Canada (the public sector balance) as well as the net lending or borrowing by the private sector (households, unincorporated businesses and corporations), both as a percentage of GDP for the period from 1961 to 2011. As can be seen, whenever the public sector is running a deficit, the private sector as a whole is running a surplus, and vice versa. When the sum of the two balances does not add up to zero, it represents the equivalent of a surplus or a deficit in the foreign sector (not shown here). Therefore, the public budget really does reflect - almost like a mirror the private sector's net accumulation of savings. This evidence refutes the claims made by austerity advocates about the dangers of deficit spending. It leads us to conclude 


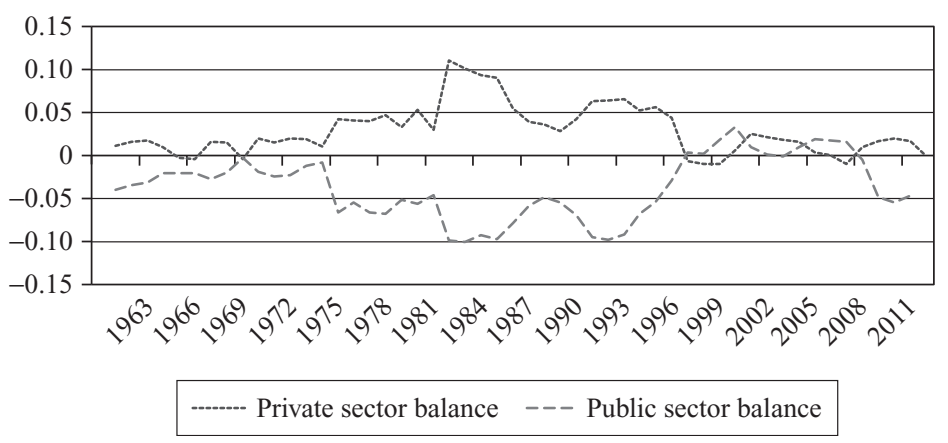

Source: Statistics Canada, CANSIM Tables no. 378-0018, 378-0021, 378-0022, 378-0023, 378-0030, 378-0039, 378-0040.

\section{Figure 7 Public sector vs private sector balances, Canada 1961-2011}

that their claims should be dismissed as irrelevant, misinformed or perhaps as sheer propaganda.

The objections to financing government expenditures through deficit spending are often justified by fears of inflation associated with the government creating too much money. However, the astute observer will notice that there is no such possibility for an excess supply of money since all the money that was created has been necessarily demanded (Lavoie 1999). When workers seek jobs, they are demanding money. When contractors are hired to build a needed school, a hospital or a bridge, they demand money in compensation. Therefore, the supply of money is always equal to the demand for money. The supply of money cannot exceed the demand for it because the supply is endogenously determined by the demand emanating from private agents (Lavoie 2001; Wray 1998).

In fact, when the government permits unemployment to exist by refusing to hire workers and neglects the infrastructure by not building the needed schools, roads, and so on, it is voluntarily choosing to suppress the demand for money and keep it arbitrarily low. Suppressing the demand for money has real implications on real people because it directly affects their livelihood: it deprives them of opportunities to have access to jobs. This is why austerity is a threat to democracy. And as Smithin (2003-2004, p. 15) put it, '[m]etaphorically speaking, by shrinking the elastic production of credit money, the "life force" of capitalism is drained from the body. An elastic supply of credit, and deficit financing, is actually a necessary condition for any economic expansion in the real sector.' Understanding money, and how public spending is financed, is essential because it effectively liberates the government from being subject to an imaginary budget constraint and allows it to actively intervene to fill the gap of under-utilised capacity of society as a whole - that is, to strive to achieve full employment, growth and prosperity. This is the indelible task of the creative state, which should be the antidote to austerity and the concomitant rise of new dictatorships.

\section{CONCLUSION}

In a class society, it is expected that the distribution of income and wealth results in conflicts among the different social classes, which rationally resort to all sorts of 
means to defend their interests. In the latest stage of capitalism - characterized by the dominance of money managers - the favored and omnipresent means used by the dominant class has been fiscal austerity. This paper has shown that austerity, and the set of policies associated with it, are designed with the intention and objective to destroy the social security system, deregulate markets and privatize public sector activities to serve the dominant financial interests. It has also argued that prolonged periods of austerity have led to economic stagnation and severe recessions that threaten not only the institutions but the foundations of the whole capitalist system. To prevent the economy from sliding further down into depression, the paper proposes an alternative strategy in which the state should re-appear as an entity that represents and defends the interests of the greater majority by regulating all markets and ensuring full employment, growth and prosperity through the intelligent use of public finance.

\section{REFERENCES}

Bellofiore, R. (2011), 'Crisis Theory and the Great Recession: A Personal Journey From Marx to Minsky', Research in Political Economy, 27, 81-120.

Boniface, P. (2011), Les Intellectuels Faussaires: Le Triomphe Médiatique des Experts en Mensonge, Paris: Éditions JC Gawsewitch.

Bougrine, H. (2010), 'The Stabilizing Role of Government Spending', in Bougrine, H. and M. Seccareccia (eds), Macroeconomic Analysis: Competing Views, Toronto: Emond Montgomery Publications, pp. 165-175.

Bougrine, H. and M. Seccareccia (2002), 'Money, Taxes, Public Spending and the State Within a Circuitist Perspective', International Journal of Political Economy, 32 (3), 58-80.

Campbell, B. and J. Loxley (eds) (1989), Structural Adjustment in Africa, New York: St. Martin's Press.

Credit Suisse (2011), The Credit Suisse Global Investment Returns Yearbook, available online at www.credit-suisse.com.

Crotty, J. (2012), 'The Great Austerity War: What Caused the US Deficit Crisis and Who Should Pay to Fix it?', Cambridge Journal of Economics, 36, 79-104.

Davidson, P. (2010), 'Making Dollars and Sense of the U.S. Government Debt', Journal of Post Keynesian Economics, 32 (4), 661-665.

Foley, D. K. (2010), 'Lineages of Crisis Economics from the 1930s: Keynes, Hayek, and Schumpeter', Eastern Economic Journal, 36, 413-422.

Frank, T. (2012), Pity the Billionaire: The Hard-Times Swindle and the Unlikely Comeback of the Right, New York: Metropolitan Books.

Galbraith, J. K. (2008), The Predator State: How Conservatives Abandoned the Free Market and Why Liberals Should Too, New York: Free Press.

Godley, W., and M. Lavoie (2007), 'Fiscal Policy in a Stock-Flow Consistent (SFC) Model', Journal of Post Keynesian Economics, 30 (1), 79-100.

Henry, J. F. (2008), 'The Theory of the State: The Position of Marx and Engels', Forum for Social Economics, 37 (1), 13-25.

Hodgson, G. M. (2009), 'The Great Crash of 2008 and the Reform of Economics', Cambridge Journal of Economics, 33 (6), 1205-2121.

Keynes, J. M. (1936), The General Theory of Employment, Interest and Money, London: Macmillan.

Lavoie, M. (1993), 'L’Idéologie des Discours Budgétaires Fédéraux: Plus ça Change, Plus c'est Pareil!' in Seccareccia, M. and P. Paquette (eds), Les Pièges de l'Austérité, Dette Nationale et Prospérité Economique: Alternative a L'orthodoxie, Presses de l'Université de Montréal, pp. $105-130$. 
Lavoie, M. (1999), 'The Credit-led Supply of Deposits and the Demand for Money: Kaldor's Reflux Mechanism as Previously Endorsed by Joan Robinson', Cambridge Journal of Economics, 23 (1), 103-114.

Lavoie, M. (2001), 'Endogenous Money in a Coherent Stock-Flow Framework', Economics Working Paper 325, The Levy Economics Institute of Bard College, Annandale-on-Hudson.

Lerner, A. (1943), 'Functional Finance and the Federal Debt', Social Research, 10 (1), 38-51.

Loxley, J. (1998), Interdependence, Disequilibrium and Growth: Reflections on the Political Economy of North-South Relations at the Turn of the Century, London: Macmillan.

Marx, K. (1887 [1967]), Capital: A Critique of Political Economy, Vol. 1, New York: International Publishers.

Minsky, H. P. (1986), Stabilizing an Unstable Economy, New Haven, CT: Yale University Press.

Palley, T. I. (2007), 'Financialization: What It Is and Why It Matters', Working Paper 525, The Levy Economics Institute.

Palley, T. I. (2009), America's Exhausted Paradigm: Macroeconomic Causes of the Financial Crisis and Great Recession, Washington, DC: New American Foundation.

Parguez, A. (2002), 'A Monetary Theory of Public Finance', International Journal of Political Economy, 32 (3), 80-97.

Rajan, R. G. (2012), 'The Corporation in Finance', NBER Working Paper No. 17760, available online at: http://www.nber.org/papers/w17760.

Schor, J. B. (1993), The Overworked American: The Unexpected Decline Of Leisure, New York: Basic Books.

Skidelsky, R. (2010), 'The Crisis of Capitalism: Keynes Versus Marx', The Indian Journal of Industrial Relations, 45 (3), 321-335.

Smithin, J. (2003-2004), 'Can we Afford to Pay for Social Programs?', Studies in Political Economy, 71/72, 163-176.

Stiglitz, J. E. (2002), Globalization and Its Discontents, London: Penguin Books.

Stiglitz, J. E. (2011), 'Of the 1\%, by the $1 \%$, for the 1\%', Vanity Fair, May, available online: http://www.vanityfair.com/society/features/2011/05/top-one-percent-201105.

Toronto Star, The (2012), 'Conservatives' Wage Model Will Hurt all Workers, Unions Say', 15 May, accessed online at http://www.thestar.com/news/canada/article/1178645-ei-reformchanges-will-drive-down-wages-for-everyone.

Toye, J. (2000), 'Fiscal Crisis and Fiscal Reform in Developing Countries', Cambridge Journal of Economics, 24 (1), 21-44.

Valiani, S. (2012), Rethinking Unequal Exchange: The Global Integration of Nursing Labour Markets, Toronto: University of Toronto Press.

Whalen, C. J. (2008), 'Toward "Wisely Managed" Capitalism: Post-Keynesian Institutionalism and the Creative State', Forum for Social Economics, 37 (1), 43-60.

Wray, L. R. (1998), Understanding Modern Money, Cheltenham, UK: Edward Elgar.

Wray, L. R. (2010), 'The Social and Economic Importance of Full Employment', in Bougrine, H. and M. Seccareccia (eds), Macroeconomic Analysis: Competing Views, Toronto: Emond Montgomery Publications, pp. 219-228.

Wray, R. (1999), 'Surplus Mania: A Reality Check', Policy No. 3, Levy Economics Institute, available online at http://www.levyinstitute.org/pubs/pn99_3.pdf.

Yalnizyan, A. (2010), The Rise of Canada's Richest 1\%, Ottawa: Canadian Centre for Policy Alternatives, available online at http://www.policyalternatives.ca/sites/default/files/uploads/ publications/National\%20Office/2010/12/Richest\%201\%20Percent.pdf. 